\title{
NÁVRH MIESTNEHO ÚZEMNÉHO SYSTÉMU EKOLOGICKEJ STABILITY PRE ÚZEMIE OBCE BZOVÍK
}

\author{
Andrej Raniak, László Miklós
}

\begin{abstract}
Aim of presented paper is creation of proposition of Territorial System of Ecological Stability (TSES). TSES is unique type of ecological network used in Slovakia and Czech Republic. TSES provides solutions for fragmentation of habitats and their loss by creating a network of ecologically stabile parts of landscape. There are three hierarchical levels on which TSES is created: national, regional and local. Creating TSES on local level ensures that the whole ecological network will work. Cadastral area of Bzovik offers typical landscape aspects of small agricultural village of central Slovakia. Following proposal of local TSES was created using gathered data enhanced by field survey. The proposition of local TSES consists of proposition of framework of local TSES and ecostabilizing measures.
\end{abstract}

Keywords: ecological stability, ecological network, Territorial system of Ecological stability

\section{Úvod}

Jedným z ciel'ov efektívneho využívania krajiny je vytvorenie funkčnej štruktúry krajiny za existencie rôznych krajinných prvkov, aj prvkov s nízkou ekologickou stabilitou (Miklós, Diviaková, Izakovičová, 2018). Pri tvorbe socioekonomickej infraštruktúry a neustálej expanzii pol'nohospodárskych a priemyselných objektov vznikli izolované segmenty krajiny. Ekologicky významné segmenty krajiny dnes existujú ako fragmenty prírody, resp. izolované ostrovy bez možnosti migrácie živých organizmov a vzájomnej výmeny ich genetických informácií. Územný systém ekologickej stability (ÚSES) je nástrojom na riešenie tohto problému, ked’že jeho výsledkom je vytvorenie kontinuálnej siete ekologicky stabilných segmentov krajiny. Tvorba ÚSES v SR prebieha na 3 úrovniach: nadregionálna, regionálna a miestna. Ciel'om predloženej práce je vytvorenie návrhu miestneho územného systému ekologickej stability (MÚSES) pre územie obce Bzovík.

\section{Teoreticko-metodické východiská}

Pri spracovaní práce sme vychádzali z publikácie s názvom: „Metodické pokyny na vypracovanie projektov regionálnych a miestnych ÚSES“ (Izakovičová, 
2000). V prvom kroku, v analýze, sme spracovali priestorové informácie do mapových výstupov. Východiskovými materiálmi pre primárnu krajinnú štruktúru (PKŠ) bola Komplexná geologická informačná báza pre potreby ochrany prírody a manažmentu krajiny (Malík a kol., 2011) a Geobotanická mapa ČSSR - Slovenská republika (Michalko a kol., 1986). V rámci spracovania súčasnej krajinnej


ortorektifikovaných leteckých snímok. Priestorové parametre prvkov SKŠ sme aktualizovali informáciami zistenými terénnym prieskumom v porovnaní s georeferencovanými satelitnými snímkami. Prvky SKŠ sme zatriedili podla práce Miklós, Diviaková, Izakovičová (2018). V rámci spracovania terciárnej krajinnej štruktúry sme vytvorili mapy socio-ekonomických javov (SEJ) s pozitívnym dopadom na ekologickú stabilitu krajiny a SEJ s negatívnym dopadom na ekologickú stabilitu krajiny, prvky ohrozujúce alebo naopak podporujúce ekologickú stabilitu krajiny boli zatriedené podl'a práce Miklós, Diviaková, Izakovičová (2018). Výstupy z analýz PKŠ sme spracovali do jednotlivých máp, ktoré sme metódou superpozície kartografických podkladov spojili v kroku syntéz do mapy abiotických komplexov (ABK). Spracované údaje o SKS̆ sme interpretovali za účelom zistenia ekologickej stability jednotlivých skupín SKŠ. Pridel'ované stupne ekologickej stability sú rozdelené podl'a stupnice pre hodnotenie významu krajinného segmentu z hl'adiska ekologickej stability (Löw a kol.,1995). Na základe spracovaných informácií a mapových podkladov sme navrhli kostru MÚSES a ekostabilizačné opatrenia.

\section{Vymedzenie územia obce Bzovík}

Obec Bzovík sa nachádza v Banskobystrickom kraji, okrese Krupina (mapa 1). Z hl'adiska geologických pomerov tvoria podložie na území obce neovulkanity. Podl'a geomorfologického členenia zvolené územie patrí do oblasti Slovenské stredohorie, celku Krupinská planina, podcelku Bzovícka pahorkatina (Mazúr, Lukniš, 1986). Morfologicky ide o stredne členitý pahorkatinový až mierne členitý vrchovinový typ krajiny. Z hl'adiska klimatickogeografických podmienok sa územie vyznačuje horskou klímou, teplou. Podl’a hydrogeologických rajónov leží obec v rajóne V094 - neovulkanity Krupinskej planiny, Ostrôžok a Pôtorskej pahorkatiny. Prevládajúcim pôdnym typom sú kambizeme (Burkovský, 1998). Z pohl'adu fytogeografického členenia Slovenska (Futák, 1980) patrí územie do oblasti západokarpatskej flóry (Carpaticum occidentale), obvodu Slovenské stredohorie. Podl'a fytogeograficko-vegetačného členenia (Plesník, 2002) územie patrí do dubovej zóny, horskej podzóny a sopečnej oblasti. Podl'a zoogeografického členenia limnického biocyklu je územie súčastou pontokaspickej provincie, stredoslovenskej časti. Podl’a členenia terestrického biocyklu leží územie $\mathrm{v}$ podkarpatskom úseku v provincii listnatých lesov (Hrnčiarová, ed., 2002). 
Mapa 1: Poloha obce Bzovík v rámci Slovenska

Map 1: Position of Bzovík Municipality in Slovakia



\section{Analýzy primárnej, sekundárnej a terciárnej krajinnej štruktúry}

Z hl'adiska morfograficko-polohových typov reliéfu viac než polovicu územia tvoria svahové plošiny. Takmer $10 \%$ územia zaberajú svahové doliny v celku, ako aj úzke nivy horských potokov či svahové plošiny. Prehl'ad zastúpenia morfologicko-polohových typov reliéfu poskytuje tab. 1. Prehl'ad sklonitosti reliéfu poskytuje tab. 2. Na území prevláda sklonitost' v intervale $3^{\circ}-7^{\circ}$. Najzastúpenejším geologickým podkladom sú vulkanity, s menším zastúpením sa vyskytujú aj deluviálne a fluviálne sedimenty (tab. 3). Z hl'adiska pôdnych subtypov je najzastúpenejším kambizem typická (tab. 4). Najviac plošne zastúpenými biotopmi potenciálnej prirodzenej vegetácie na území sú dubovo cerové lesy a dubovo-hrabové lesy karpatské. Prehl'ad zastúpenia biotopov potenciálnej prirodzenej vegetácie je uvedený v tab. 5 .

Tab. 1 : Zastúpenie morfologicko-polohových elementárnych foriem reliéfu

Table 1: Representation of morphological-position elementary relief forms

\begin{tabular}{|l|c|l|}
\hline $\begin{array}{c}\text { Morfograficko - } \\
\text { polohový typ }\end{array}$ & Celková plocha [ha] & $\begin{array}{c}\text { Percentuálne } \\
\text { vyjadrenie [\%] }\end{array}$ \\
\hline kupolovitý vrchol & 0,27 & 0,02 \\
\hline plochý vrchol & 46,91 & 3,61 \\
\hline vrcholová plošina & 22,94 & 1,77 \\
\hline chrbát & 94,62 & 7,29 \\
\hline sedlo & 2,3 & 0,18 \\
\hline svahová plošina & 117,68 & 9,06 \\
\hline svah transportný & 682,04 & 52,53 \\
\hline svahová dolina vcelku & 121,09 & 9,33 \\
\hline výmol' až strž & 91,03 & 7,01 \\
\hline úzka niva horských potokov & 119,39 & 9,20 \\
\hline
\end{tabular}


Tab. 2: Sklonitost' reliéfu

Table 2: Slope of relief

\begin{tabular}{|l|c|c|}
\hline \multicolumn{1}{|c|}{ Interval sklonu } & Celková plocha [ha] & Percentuálne zastúpenie [\%] \\
\hline$\left(1^{\circ}, 3^{\circ}>\right.$ & 347,10 & 26,74 \\
\hline$\left(3^{\circ}, 7^{\circ}>\right.$ & 463,95 & 35,74 \\
\hline$\left(7^{\circ}, 12^{\circ}>\right.$ & 388,54 & 29,33 \\
\hline$\left(12^{\circ}, 17^{\circ}>\right.$ & 59,57 & 4,59 \\
\hline$\left(17^{\circ}, 25^{\circ}>\right.$ & 39,11 & 3,01 \\
\hline
\end{tabular}

Tab. 3: Zastúpenie jednotiek geologického podkladu

Table 3: Representation of units of geological base

\begin{tabular}{|l|r|r|}
\hline \multicolumn{1}{|c|}{ Geologický podklad } & $\begin{array}{c}\text { Celková plocha } \\
\text { [ha] }\end{array}$ & $\begin{array}{c}\text { Percentuálne } \\
\text { zastúpenie [\%] }\end{array}$ \\
\hline deluviálne sedimenty (svahoviny) & 114,74 & 8,84 \\
\hline deluviálno-fluviálne sedimenty & 0,63 & 0,05 \\
\hline fluviálne sedimenty s pokryvom & 148,17 & 11,41 \\
\hline proluviálne sedimenty & 2,84 & 0,22 \\
\hline vulkanity andezitov & 827,06 & 63,70 \\
\hline vulkanity/sedimenty andezitov & 204,83 & 15,78 \\
\hline
\end{tabular}

Tab. 4: Zastúpenie pôdnych subtypov

Table 4: Representation of soil sub-types

\begin{tabular}{|l|r|r|}
\hline \multicolumn{1}{|c|}{ Pôdny subtyp } & $\begin{array}{c}\text { Celková plocha } \\
\text { [ha] }\end{array}$ & $\begin{array}{c}\text { Percentuálne } \\
\text { zastúpenie [\%] }\end{array}$ \\
\hline fluvizem typická & 120,49 & 9,28 \\
\hline kambizem typická & 873,34 & 67,27 \\
\hline pseudoglej luvizemný & 304,44 & 23,45 \\
\hline
\end{tabular}

Tab. 5: Zastúpenie biotopov potenciálnej prirodzenej vegetácie

Table 5: Representation of habitats of potential natural vegetation

\begin{tabular}{|l|r|r|}
\hline \multicolumn{1}{|c|}{ Potenciálna prirodzená vegetácia } & $\begin{array}{c}\text { Celková } \\
\text { plocha [ha] }\end{array}$ & $\begin{array}{c}\text { Percentuálne } \\
\text { zastúpenie [\%] }\end{array}$ \\
\hline Dubovo-brestovo-jaseňové nížinné lužné lesy & 167,26 & 12,88 \\
\hline Dubovo cerové lesy & 534,41 & 41,16 \\
\hline Dubovo-hrabové lesy karpatské & 592,88 & 45,67 \\
\hline Jaseňovo jelšové podhorské lužné lesy & 3,71 & 0,29 \\
\hline
\end{tabular}


Spracovaním priestorových informácií o SKŠ sme zistili, že prevládajúcim prvkom SKŠ je orná pôda, ktorá zaberá 45,21 \% územia respektíve 568,97 ha. Druhým najviac zastúpeným prvkom sú lesy, ktoré zaberajú 29,17 \% územia. V rámci lesov prevládajú hrabové dubiny, dubové hrabiny, dubiny ale aj porasty agátu bieleho (Robinia pseudoacacia). Kategórie SKŠ a ich zastúpenie v území približuje tab. 6 .

Tab. 6: Kategórie prvkov SKŠ a ich zastúpenie v území Table 6: Categories of SKS and their share

\begin{tabular}{|l|r|r|}
\hline \multicolumn{1}{|c|}{ Prvok SKŠ } & Plocha [ha] & Percentuálne zastúpenie [\%] \\
\hline Cestné komunikácie & 15,35 & 1,18 \\
\hline Historická pamiatka & 0,60 & 0,05 \\
\hline Lesy & 378,88 & 29,18 \\
\hline Agátiny & 58,61 & 4,51 \\
\hline Ceriny & 54,45 & 4,19 \\
\hline Cerové dubiny & 14,06 & 1,08 \\
\hline Dubiny & 67,25 & 5,18 \\
\hline Dubové hrabiny & 81,12 & 6,25 \\
\hline Hrabiny & 3,41 & 0,26 \\
\hline Hrabové ceriny & 5,85 & 0,45 \\
\hline Hrabové dubiny & 94,13 & 7,25 \\
\hline Nelesná drevinová vegetácia & 23,37 & 1,80 \\
\hline Brehové porasty & 6,28 & 0,48 \\
\hline NDV - líniová & 8,74 & 0,67 \\
\hline NDV - skupinová & 8,35 & 0,64 \\
\hline Obytné areály & 54,04 & 4,16 \\
\hline Zastavaná plocha & 48,29 & 3,72 \\
\hline Cintorín & 0,92 & 0,07 \\
\hline Prídomové záhrady & 3,81 & 0,29 \\
\hline Športový areál & 1,02 & 0,08 \\
\hline Orná pôda & 586,97 & 45,21 \\
\hline Pol'nohospodárske areály & 5,76 & 0,44 \\
\hline Pol'nohospodársky areál & 1,69 & 0,13 \\
\hline Pol'nohospodársky areál - & 4,07 & 0,31 \\
nevyuživaný & 17,43 & 10,36 \\
\hline Sad & 7,87 & 0,61 \\
\hline Solárna elektráreň & 207,99 & 16,02 \\
\hline Trvalé trávne porasty (TTP) & & \\
\hline TTP - extenzívne & & \\
\hline TTP - intenzívne & & \\
\hline
\end{tabular}


Analýzou údajov o terciárnej krajinnej štruktúre sme $\mathrm{z}$ negatívne pôsobiacich SEJ na území identifikovali pásmo hygienickej ochrany pol'nohospodárskych objektov, v strede východnej časti územia a ochranné pásmo ciest II. a III. triedy. V rámci pozitívne vplývajúcich SEJ sme identifikovali hospodárske a ochranné lesy, chránené pôdy 3. a 4. kategórie kvality a ochranné pásmo vodárenského zdroja.

\section{Krajinnoekologické syntézy}

Výsledkom syntéz bolo spracovanie ABK. Spracovaním abiotických komplexov sme na území identifikovali 84 rôznych kombinácií (morfologickopolohových jednotiek, intervalov sklonu, geologického podkladu, pôdneho subtypu). Najzastúpenejšia jednotka ABK je transportný svah so sklonom $\mathrm{v}$ intervale $\left(7^{\circ}, 12^{\circ}>\right.$, s geologickým podložím tvoreným vulkanitmi a pôdnym subtypom - kambizem typická. Tento komplex abiotických podmienok územia zaberá $16,45 \%$.

\section{Krajinnoekologické interpretácie}

Až 45,55 \% územia spadá do 2. Stupňa významnosti, teda je to územie s malým významom. Ide o vel'koblokovú ornú pôdu, ktorá obopína intravilán, jemu prilahlé TTP a agátiny. Územie s najvyššou ekologickou stabilitou reprezentujú lesy tiahnuce sa od severu územia juhozápadne popri hranici obce. Výsledný koeficient ekologickej stability $\left(\mathrm{K}_{\mathrm{es}}\right)$ územia bol = 3,04.

\section{Návrhy kostry MÚSES a ekostabilizačných opatrení}

Výsledný návrh kostry MÚSES tvoria 4 biocentrá, 3 biokoridory a dva interakčné prvky. Priestorový priemet kostry MÚSES ako aj navrhnutých ekostabilizačných opatrení zobrazuje mapa 2.

Miestne biocentrum Vinica $-\mathrm{MBc1}$

Rozloha: 115,7 ha

Lokalita sa nachádza na severnom cípe územia. Ide o lesné spoločenstvá rozdelené extenzívne využívanými TTP, nachádzajúce sa medzi obcou Bzovík a mestom Krupina. Lesné spoločenstvá sú najmä dubiny a hrabiny. Približne v strede sa nachádzajú ochranné lesy, obkolesené hospodárskym lesom. V rámci návrhu biocentra, taktiež navrhujeme ponechat' TTP na sukcesný zárast, ktorý už $\mathrm{v}$ lokalite prebieha. 
Mapa 2: Návrh kostry MÚSES a ekostabilizačných opatrení (Raniak, 2018) Map 2: The design of the MÚSES skeleton and ecostabilization measures (Raniak, 2018)

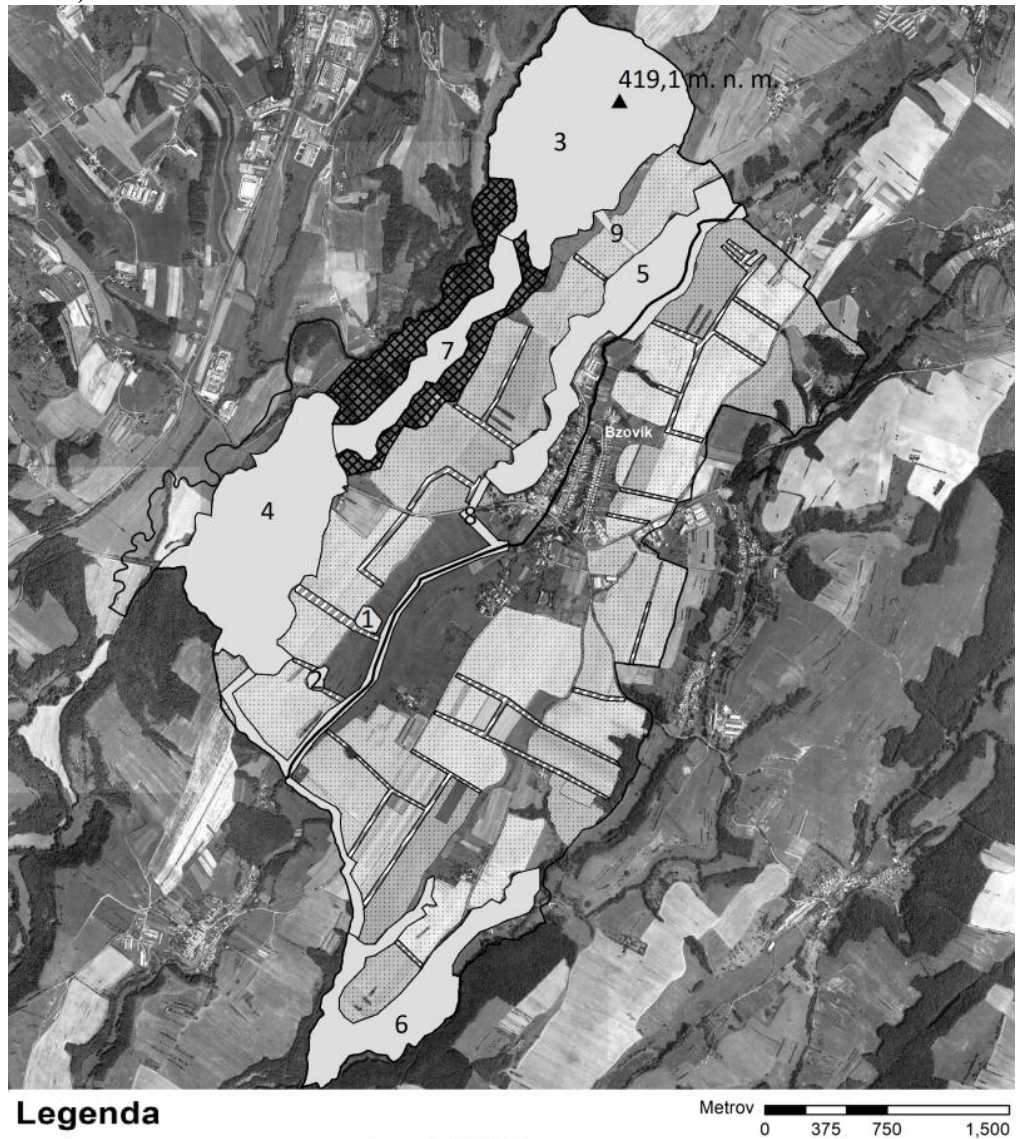

- Bzovská vinica

Návrh MÚSES

Hranica územia obce Bzovik

Čekovský potok

\section{Ekostabilizačné opatrenia}

EsOp1
EsOp 2
EsOp 3

\begin{tabular}{|c|c|}
\hline 1 & Ip1 - Nad Sýkorou \\
\hline 2 & Ip2 - Za hájom \\
\hline 3 & MBc1 - Vinica \\
\hline 4 & MBc2 - Nad mlynom \\
\hline 5 & MBc3 - Agátiny \\
\hline 6 & MBc4 - Na kopanickách \\
\hline 7 & MBk1 - Prieloh \\
\hline 8 & MBk2 - Čekovský potok \\
\hline 9 & MBk3 - Vinica - Agátiny \\
\hline
\end{tabular}

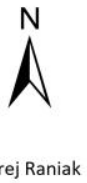


Miestne biocentrum Nad mlynom - MBc2

Rozloha: 98,80 ha

Ide o lokalitu na západe obce. Biocentrum je tvorené lesmi - hrabovými dubinami. Susedné plochy sú najmä pol’nohospodárske orné pôdy. Zo severnej strany susedí s hrabovými porastami a TTP (extenzívnymi aj intenzívnymi).

Miestne biocentrum Agátiny - Mbc3

Rozloha: 54,75 ha

Biocentrum je tvorené porastmi Agátu bieleho severne od obce. Tieto porasty majú pôdoochrannú funkciu a sú vyhlásené za ochranné lesy. Stredom územia sa tiahne extenzívne využívaná lúka so značným sukcesným zárastom.

Miestne biocentrum Na kopaničkách - MBc4

Rozloha: 54,49 ha

Lokalita sa nachádza na južnom cípe územia. Biocentrum tvoria ceriny susediace s ornými pôdami zo severnej strany.

Miestny biokoridor Prieloh - MBk 1

Rozloha: 27,86 ha

Biokoridor sa nachádza blízko západnej hranici územia. Spája miestne biocentrum Vinice $s$ južne položeným biocentrom Nad mlynom. Je tvorený dubovými hrabinami. Susedí s TTP z východnej aj západnej strany, a čast’ami lesných spoločenstiev ktoré na danej lokalite tvoria mozaiku sextenzívne využívanými TTP.

Miestny biokoridor Čekovský potok - MBk 2

Rozloha: 26,42 ha

Biokoridor spája 3 biocentrá - MBc Agátiny, MBc Nad mlynom a MBc Na kopaničkách. Z najväčšej časti je tvorený brehovými porastami Čekovského potoka smerujúce južne od intravilánu. V rámci návrhu odporúčame rozšírenie pásov brehovej vegetácie potoka.

Miestny biokoridor Vinica - Agátiny - MBk 3

Rozloha: 1,59 ha

Ide o funkčné prepojenie Biotopov MBc 1 a MBc 3, ktoré od seba oddel'uje pás ornej pôdy. Na vytvorenie navrhovaného biokoridoru je potrebné vytvorenie 
pásu vegetácie, čo by malo pozitívy dopad aj z pohl’adu ekologickej stability územia, z dôvodu rozdelenia vel'koblokovej ornej pôdy. Biokoridor je navrhnutý na mieste kde sa kedysi nachádzala líniová NDV.

Ip1 Nad Sýkorou a Ip2 Za hájom

Oba interakčné prvky sú tvorené skupinovou NDV. Nachádzajú sa na hranici intenzívne využívaných TTP a ornej pôdy, vblízkosti miestneho biokoridoru Čekovský potok. Tieto prvky majú pozitívny vplyv na spomínaný biokoridor a jeho fungovanie.

Ekostabilizačné opatrenia (EsOp)

EsOp1 - návrh optimálneho využívania pol’nohospodárskej krajiny

V rámci tohto opatrenia navrhujeme využívanie osevných postupov s ochranným účinkom na pôdu, dodržiavanie zásad striedania plodín a využívanie odl'ahčených pojazdových mechanizmov. Účelom opatrenia je predchádzanie zhutňovaniu pôdy a rizika erózie.

EsOp 2 - sukcesný zárast TTP

Ekostabilizačné opatrenie spočíva $\mathrm{v}$ ponechaní pril'ahlých TTP sukcesnému zárastu, ktorého proces už prebieha na extenzívne využívaných TTP.

EsOp3 - rozdelenie vel'koblokovej ornej pôdy

Navrhované ekostabilizačné opatrenie spočíva vo výsadbe respektíve rozšírení už existujúcich líniových NDV. Týmto spôsobom navrhujeme rozdelit' vel'koblokovú ornú pôdu s ciel'om zvýšenia ekologickej stability územia.

\section{Záver}

Územie sa z vel'kej časti skladá z pol'nohospodársky využívaných pôd, ktoré majú nízku ekologickú stabilitu (2. stupeň). Zároveň je však v obci viacero plôch s vysokou ekologickou stabilitou, ide najmä o lesné spoločenstvá so stupňom ekologickej stability 4 - 5 .

Na základe výskytu lesných biotopov vyznačujúcich sa najvyšším stupňom ekologickej stability sme vyčlenili 4 miestne biocentrá. Navrhnuté biocentrá sa dotýkajú hranice územia a pokračujú aj za jeho hranicou. Ich funkčné prepojenie sme sa snažili zaistit' s prihliadaním na distribúciu prvkov SKŠ. V prípade návrhu 1. biokoridoru sme využili existujúci lesný biotop. Pri návrhu 2. biokoridoru sme 
využili existujúce prvky NDV a v poprípade 3. biokoridoru sme navrhli jeho vytvorenie prostredníctvom doplnenia NDV na miestach, kde sa pôvodne vyskytovali. Zároveň sme brali ohl'ad pre možné napojenie v prípade spracovania projektov MÚSES na susedných územiach. Taktiež sme navrhli 2 interakčné prvky, konkrétne na existujúcej skupinovej NDV v blízkosti biokoridoru Čekovský potok.

$\mathrm{V}$ rámci ekostabilizačných sme sa sústredili na pol’nohospodársky využívanú čast' krajiny. Najväčší problém predstavovala vel'ká plocha pol'nohospodársky využívaného územia. Tento problém sme navrhli riešit' prostredníctvom ekostabilizačného opatrenia EsOp3, v rámci ktorého sme vytvorili návrh na rozdelenie orných plôch líniovou NDV. Jednotlivé pásy NDV sme navrhli na miestach, kde bolo možné ich napojit' na existujúcu NDV, alebo sa tam nachádzali vysadené solitéry stromov, prípadne rozšírenie existujúcej NDV. Toto opatrenie vedie k zvýšeniu celkovej ekologickej stability územia. Pre jednotlivé plochy ornej pôdy sme tiež navrhli šetrnejšie agrotechnické postupy s ciel'om obmedzit' riziko znehodnotenia pôd. Ekostabilizačné opatrenia sme navrhli aj pre TTP susediace s biokoridorom MBk1 Prieloh, s ciel'om na jednej strane obmedzit' intenzívne využitie TTP, no zároveň ponechat' na samo vývoj mozaiku lesných spoločenstiev a TTP. Návrh MÚSES môže byt' využitý ako základný krajinnoekologický podklad pre pozemkové úpravy, je taktiež povinným podkladom pre územno-plánovacie dokumentácie. Výsledky práce teda môžu byt' využité samosprávou obce pri zapracovaní do rozvojových dokumentácií ako aj projektantmi územno-plánovacích dokumentácií a projektov pozemkových úprav.

\section{Literatúra}

BURKOVSKÝ, J. 1998. Navrhovaná chránená krajinná oblast' Krupinská planina In Urban, P., Bitušík, P. (eds) Príroda krupinskej planiny a jej ochrana. Bratislava: Ministerstvo životného prostredia Slovenskej republiky, Banská Bystrica: Slovenská agentúra životného prostredia, 186 s. ISBN 80- 88850-27-4 186.

FUTÁK J. 1980. Fytogeografické členenie. In Mazúr, E. (ed.) Atlas Slovenskej socialistickej republiky. Bratislava, s. 88, mapa VII/14.

HRNČIAROVÁ, T. ed. 2002. Atlas krajiny Slovenskej republiky. Bratislava: MŽP SR, Banská Bystrica: SAŽP, 2002. 344 s.

IZAKOVIČOVÁ, Z. - HRNČIAROVÁ, T. - KRÁLIK, J. - LIŠKA, M. - MIKLÓS, L. - MOYZEOVÁ, M. - PAUDITŠOVÁ, E. - RUŽIČKOVÁ, H. - ŠÍBL, J. TREMBOŠ, P. 2000. Metodické pokyny na vypracovanie projektov regionálnych územných systémov ekologickej stability a miestnych územných systémov ekologickej stability. Bratislava: MŽP SR, Združenie KRAJINA 21, $155 \mathrm{s.}$

LÖW, J. a kol. 1995. Rukovět' projektanta místního ÚSES. Brno: Agroprojekt, 1995. $124 \mathrm{~s}$. 
MALÍK, P. - BAHNOVÁ, N. - IVANIČ, B. - KOČICKÝ, D. - MARETTA, M. ŠPILÁROVÁ, I. - ŠVASTA, J. - ZVARA, I. 2011. Komplexná geologická informačná báza pre potreby ochrany prírody a manažmentu krajiny. Bratislava: MŽP SR, ŠGÚDŠ.

MAZÚR, E. - LUKNIŠ, M. 1986. Geomorfologické členenie SSR a ČSSR. Bratislava: Slovenská kartografia.

MICHALKO, J. - BERTA, J. - MAGIC, D. 1986. Geobotanická mapa ČSSR Slovenská republika. Bratislava: VEDA, 1986. $162 \mathrm{~s}$.

MIKLÓS, L. - DIVIAKOVÁ, A. - IZAKOVIČOVÁ, Z. 2018. Ecological networks and territorial systems of ecological stability. Cham: Springer, 2018. $159 \mathrm{p}$.

PLESNÍK, P. 2002. Fytogeograficko-vegetačné členenie 1: 1000 000. In Hrnčiarová, T. (ed) Atlas krajiny Slovenskej republiky. Bratislava: MŽP SR, Banská Bystrica: SAŽP, s. 113.

RANIAK, A. 2018. Návrh miestneho územného systému ekologickej stability pre kataster obce Bzovík. Zvolen: Technická univerzita vo Zvolene, 2018. $70 \mathrm{~s}$.

\section{PROPOSAL OF LOCAL TERRITORIAL SYSTEM OF ECOLOGICAL STABILITY FOR BZOVÍK VILLAGE}

\section{Summary}

This paper concerns with proposal of local Territorial System of Ecological Stability (TSES) in small village in central Slovakia. Village of Bzovík represents usual aspects of land use in agriculturally oriented villages in central Slovakia. Agricultural areas make up to $45 \%$ of cadastral area of Bzovík. These areas have low index of ecological stability according to Löw et al. (1995). On the other hand, there are numerous areas of cadaster that show high indexes of ecological stability (mainly forests). Building on the gathered data about areas with high ecological stability, four of them with suitable position were chosen. These forests have role of biocentres in the proposal of TSES. Proposed biocentres (Vinica, Nad mlynom, Agátiny and $\mathrm{Na}$ kopaničkách) are located on the borders of cadastral area and they continue beyond the borders. Interconnection of chosen biocentres was proposed with consideration of distribution of current landscape structure. Biocorridor Prieloh was proposed on already existing narrow forest that connects biocentre Vinice and biocentre Nad mlynom. Second biocorridor Čekovský potok, was proposed using existing non-forest woody vegetation (NFWV) and scattered greenery. This biocorridor connects biocentres Na kopaničkách, Nad mlynom and Agátiny. Since it's the longest biocorridor, proposal also contains two interaction elements located near the center of proposed biocorridor. Third biocorridor was proposed on agricultural land. Biocorridor Vinica-Agátiny was proposed to be created by renewing the NFWV on agricultural land. The proposal of TSES was 
created taking into consideration the possibility of creating local TSES projects in cadastral areas of neighboring cities and villages, consequently these projects would be connectible. In proposal of local TSES for cadastral area of Bzovík, there are three complex ecostabilizing measures recommended. Taking into consideration that major issue of chosen area is large blocks of agricultural land, two of the ecostabilizing measures concerns with it. Ecostabilizing measure EsOp3 recommends division of mentioned large blocks of agricultural land by linear strips of NFWV. Proposed areas, where these strips could be created were chosen by possibility to connect them to existing linear NFWV or by information about practice on agricultural land, following the farming methods. Second ecostabilizing measure was proposed to ease the pressure on soil. It mainly consists of recommended agrotechnological methods and thus preventing degradation of soil and erosion. Last ecostabilizing measure concerns with grasslands next to biocorridor Prieloh. It recommends lowering the intense usage of some grasslands and leave the grasslands with extensive use for successive growth and forestation on areas where it already begun.

\section{Ing. Andrej Raniak}

Univerzita Konštantína Filozofa v Nitre

Ústav krajinnej ekológie SAV

Štefánikova 3, P.O.Box 254

81499 Bratislava

E-mail: andrej.raniak@savba.sk

Dr. h. c. prof. RNDr. László Miklós, DrSc.

Ústav krajinnej ekológie SAV

Štefánikova 3, P.O.Box 254

81499 Bratislava

E-mail: miklos@tuzvo.sk 